\title{
POLITIKK
}

\section{Global helse og internasjonal fred og sikkerhet - implikasjoner for FNs sikkerhetsråd?}

\author{
Niels Nagelhus Schia (redaktør) ${ }^{\star}$ \\ Norsk Utenrikspolitisk Institutt (NUPI), Norge \\ Louise Olsson (gjesteredaktør) \\ Peace Research Institute Oslo (PRIO), Norge \\ Ida Rødningen (gjesteredaktør) \\ Peace Research Institute Oslo (PRIO), Norge
}

Dette fokusnummeret fanger opp en pågående debatt mellom forskning og policyutvikling når det gjelder koblinger mellom helse/pandemi og sikkerhet. Det tar utgangspunkt i Dialogforumet for Norges rolle i FNs sikkerhetsråd, som er et nytt samarbeidsgrep mellom NUPI, PRIO og Utenriksdepartementet opprettet spesielt for den perioden Norge sitter i rådet. ${ }^{1}$ Forumet ble etablert for å styrke målet om en kunnskapsbasert utenrikspolitikk i forbindelse med det norske medlemskapet. I den sammenheng arrangeres til sammen åtte rundebordsmøter i 2021 og 2022.

Rundebordsmøtene er tematisk organiserte rundt sentrale problemstillinger knyttet til Sikkerhetsrådets agenda og det norske medlemskapet. Til hvert møte inviteres eksperter fra UD, forskere og eventuelt andre kunnskapsorganisasjoner med spesialkompetanse for det aktuelle møtet. Formålet er todelt (i) å kartlegge

\footnotetext{
${ }^{1}$ Dialogforumets sekretariat ledes operativt av Niels Nagelhus Schia (seniorforsker NUPI), Louise Olsson (seniorforsker PRIO) og Vegar Andreassen (UD). I sekretariatet sitter også Ulf Sverdrup (direktør NUPI), Henrik Urdal (direktør PRIO), Andreas Løvold (UD) og Ida Rødningen (forskningsassistent PRIO).
}

\footnotetext{
^Kontaktinformasjon: Niels Nagelhus Schia, e-post: nns@nupi.no

(C)2021 Niels Nagelhus Schia, Louise Olsson \& Ida Rødningen. This is an Open Access article distributed under the terms of the Creative Commons Attribution 4.0 International License (https://creativecommons.org/licenses/BY/4.0/), allowing third parties to copy and redistribute the material in any medium or format and to remix, transform, and build upon the material for any purpose, even commercially, provided the original work is properly cited and states its license. Citation: Schia, N. N., Olsson, L. E Rødningen, I. (2021). Global helse og internasjonal fred og sikkerhet-implikasjoner for FNs sikkerhetsråd? Internasjonal Politikk, 79(4), 438-443. http://dx.doi.org/10.23865/intpol.v79.3650
} 
muligheter i Sikkerhetsrådet og (ii) se på handlingsrom for Norge. Med forankring i etablert politikk og forskning på den aktuelle tematikken, utforskes grenseflater for Sikkerhetsrådet og mulighetsrom for norsk utenrikspolitikk. Møtene er derigjennom av strategisk betydning for det norske medlemskapet i Sikkerhetsrådet.

Det første rundebordsmøtet satte søkelys på helse og internasjonal fred og sikkerhet og ble avholdt den 29. april 2021 under tittelen «Global helse og internasjonal fred og sikkerhet - implikasjoner for FNs sikkerhetsråd». ${ }^{2}$ Fokusnummeret tar utgangspunkt i innlegg som ble holdt under dette rundebordet, og har som mål å belyse tematikken fra et tredelt perspektiv: policy, politikk og forskning. Fokusnummeret ligger i skjæringspunktet mellom disse, og har bidrag fra statssekretær Audun Halvorsen fra Høyre (policy/politikk) som beskriver hvordan helse og sikkerhet under Solberg-regjeringen har blitt løftet til en prioritert sak for Norge som ønsker å bidra til at konsekvensene av pandemier og globale helseutfordringer på internasjonal fred og sikkerhet hører hjemme på Sikkerhetsrådets bord og blir behandlet der. Helseambassadør og tidligere direktør for Forskningsrådet JohnArne Røttingen (policy/forskning) skriver sammen med Kristine Husøy Onarheim (seniorrådgiver i UD og forsker ved Bergen Centre for Ethics and Priority Setting in Health), og de vektlegger global helsesikkerhet som et globalt fellesgode. Videre belyser de hvordan økt interesse for dette i Sikkerhetsrådet gir muligheter og handlingsrom, men de problematiserer også hvordan dette utfordrer den måten helsetrusler tolkes på og hva slags tilnærminger den internasjonale responsen leverer. Henrik Urdal, som er direktør ved PRIO, og Ida Rødningen, som er vitenskapelig assistent ved samme institutt (forskning), trekker spesielt frem hvordan global helse og uhelse kan sees i sammenheng med voldelig konflikt, og belyser kunnskapsgrunnlaget i forskningen ved bruk av fire sett årsakssammenhenger for å forstå helse som en faktor som påvirker og påvirkes av internasjonal fred og sikkerhet og hvilke implikasjoner dette kan ha i sikkerhetsrådsammenheng.

I tillegg til at verden sto midt i en pågående pandemi i april 2021, var også Sikkerhetsrådets relevans når det gjelder nye typer sikkerhetsutfordringer ett av utgangspunktene for at det første møtet i dialogfourmet valgte tematikken helse/ pandemi og sikkerhet. For at Sikkerhetsrådet skal opprettholde sin posisjon videre inn i det 21. århundre, må det gjøres i stand til å forholde seg til nye typer trusler. Her er det et behov for å gå opp nye løyper gjennom å utforske mulige fallgruver, mulighetsrom og grenseflater. Covid-19-pandemien har på nytt satt koblinger mellom helse og internasjonal fred og sikkerhet på Sikkerhetsrådets agenda; forrige gang dette skjedde var i sammenheng med ebolautbruddet i Vest-Afrika i 2018. Parallelt med policyutviklingen har forskningen også skutt fart. Flere sterke kunnskapsmiljøer har vokst fram i Norge de siste to tiårene. Basert på deres kunnskap og på ekspertise

\footnotetext{
${ }^{2}$ Møtet ble avholdt under Chatham House Rules. Vi ønsker å rette en spesiell takk til alle forskerne, til UD og til den norske FN-delegasjonen for aktiv og kunnskapsrik deltakelse. En spesiell takk går også til Ulf Sverdrup for solid ordstyring av møtet.
} 
fra UD diskuterer dialogforumet hvordan Sikkerhetsrådets rolle kan utvikles for å gjøre verden mer robust mot framtidige helsekriser og påfølgende internasjonal uro og ustabilitet. På den måten ble det også utforsket hvordan Sikkerhetsrådet kan gjøres enda mer relevant videre inn i det 21 . århundre.

Dialogmøtet tok utgangspunkt i hva Sikkerhetsrådet allerede har gjort, samt hva forskningsfronten sier om koblingene mellom global helse og sikkerhet. Sikkerhetsrådet har tidligere kun diskutert helse relatert til beskyttelse av medisinsk og humanitært personell i konflikt (resolusjon 2286, 2016) og hiv/aids, ebola, og covid-19 og har begrenset bredde og foreløpig få verktøy på tematikken. Den første resolusjonen (se resolusjon 1308 fra 2000) handler om hiv/aids-pandemiens effekt på samfunn og sosial stabilitet, inkludert spørsmål som omhandler vold og usikkerhet, samt testing og trening av personell i FNs fredsbevarende operasjoner. I 2014 og 2018 kom Sikkerhetsrådet med resolusjoner om ebolautbruddet i Vest-Afrika og DRC. Disse er tydeligere enn tidligere resolusjoner på at utbruddet utgjør en trussel mot internasjonal fred og sikkerhet. Selv om resolusjonen fortsatt benytter ord som oppfordrer og erkjenner problemene, oppfattes ebolautbruddet som en trussel mot pågående fredsbyggingsprosesser og at det har en negativ effekt på den politiske, sikkerhetsmessige, sosioøkonomiske og humanitære situasjonen i regionen (se resolusjon 2176, 2177 og 2439 for mer informasjon). Sikkerhetsrådet fremhever her også betydningen av samordning og koordinering mellom stater, organisasjoner og internt i FN-systemet, samt solidaritet og behov for å motvirke negative effekter i sårbare stater.

Disse trendene ble enda tydeligere i 2020. Den første resolusjon på covid-19pandemien (2532) kom i juli 2020, og er en oppfordring til global våpenhvile. Resolusjon 2532 ble i 2021 fulgt opp av blant annet resolusjon 2565 om humanitære pauser og vaksinedistribusjon. Resolusjonen er betydelig bredere i tilnærming og knyttes tett opp mot internasjonal respons mot covid-19. En hovedbekymring er at den ujevne fordelingen av utstyr for å håndtere pandemien kan skape sivil uro, internasjonale konflikter eller gi næring til konspirasjonsteorier og danne grunnlag for terrorisme.

Med utgangspunkt i utviklingen var det en ambisjon for dialogmøtet å se fremover med forankring i etablert politikk. Formålet var å belyse hvordan helseutfordringer kan utgjøre reelle og alvorlige trusler mot internasjonal fred og sikkerhet. Det inkluderte hvordan Sikkerhetsrådet eventuelt skal kunne bidra til å forebygge eller dempe konfliktlinjer gjennom for eksempel resolusjoner om våpenhvile, solidaritet og vaksinedistribusjon. Mer konkret ble følgende spørsmål presentert for deltakerne.

1. Hvilke erfaringer fra forskning på krig, ustabilitet, flukt og helse kan vi trekke på for å utvikle Sikkerhetsrådet på dette feltet? Hva er koblingene mellom covid-19-håndteringen med erfaringer fra sikkerhetsimplikasjoner knyttet til andre alvorlige sykdomsutbrudd som polio, hiv/aids og ebola?

2. Hva kan konsekvensene bli av ulik tilgang til covid-19-behandling og -vaksiner, samt bruk av helsesikkerhet og covid-19-teknologi som diplomatisk virkemiddel i sikkerhets- og stormaktspolitikk (vaksinediplomati)? Og i forlengelsen av dette, hva er effektene på andre internasjonale normer - som kvinner, fred og sikkerhet? 
3. Hva kan Sikkerhetsrådet gjøre for å sikre implementering av de vedtatte resolusjoner om covid-19-pandemien? Spesifikt: Hvordan kan Sikkerhetsrådet legge til rette for vaksine-våpenhviler og humanitære pauser for vaksinering?

Dialogforumet utforsket også Sikkerhetsrådets handlingsrom gjennom å se på mandat og grenseflater mot andre organisasjoner for å undersøke hvorvidt Sikkerhetsrådet bør være en relevant aktør når det gjelder helse og sikkerhet. Dette ble sett i sammenheng med erfaringer fra andre deler av FN-systemet, samt organisasjoner som EU og AU. Mer konkret diskuterte vi i denne sammenheng følgende spørsmål:

1. Bør Sikkerhetsrådet ha en rolle her? Forholdet mellom WHO og Sikkerhetsrådet synergieffekter?

2. Hva betyr langsiktig pandemiberedskap og respons som i sikkerhetsrådssammenheng? Det kan for eksempel berøre aspekter knyttet til etterlevelse av forpliktelser, samt utveksling av kunnskap, prøver, materiale og "tidlig-varsling» (access and benefit sharing). Hva skal til, pisk eller gulrot? Eksterne reviews, eller økonomiske insentiver for etterlevelse?

3. Hvilke fordeler og ulemper er knyttet til at Sikkerhetsrådet engasjerer seg i spørsmål om global helse? Er det noen fallgruver? For eksempel er helsespørsmål ikke kun et sikkerhetspolitisk problem, hvordan bør en pandemitematikk løftes i Sikkerhetsrådet? Hvilken rolle kan Sikkerhetsrådet spille vis-a-vis andre internasjonale mekanismer og organisasjoner?

Spørsmål knyttet til helse og Sikkerhetsrådets rolle er ikke enkelt; det ble behørig belyst av deltagerne på rundebordsmøtet, samt i tekstene i dette fokusnummeret. Innleggene etterlyser dessuten et behov for videre forskning om dette tverrfaglige temaet, ikke minst for å gjøre verden bedre rustet mot framtidige globale helseutfordringer. Hvordan kan verden gjøre bruk av Sikkerhetsrådet ved neste helsekrise/ pandemi? Bør Sikkerhetsrådet ha en rolle i globale helsekriser? Foreløpig har det få verktøy i verktøykassen, kun noen få resolusjoner knyttet spesifikt til covid-19, ebola og hiv/aids. Nedenfor ligger en oversikt over de ulike UNSC-resolusjonene på helse til og med 2021:

\begin{tabular}{lll}
\hline Helsetema & Resolusjon (år) & Innhold (vinkling / tilretteleggende faktorer) \\
\hline Covid-19 & $2532(2020)^{3}$ & Vinkling 2532: \\
$2565(2021)^{4}$ & - Fokus på covid-19-pandemi, særlig land rammet av konflikt, etter \\
& konflikt eller i humanitær krise. \\
& - Krav om våpenhvile og trygg, uhindret tilgang til å kunne bidra med \\
& humanitær assistanse. \\
& - Resolusjonen pekte på uforholdsmessige negative konsekvenser \\
& for minoriteter (kvinner, flyktninger eldre, mennesker med \\
& funksjonsnedsettelse). \\
\hline
\end{tabular}

(Forts.)

\footnotetext{
${ }^{3}$ https://undocs.org/en/S/RES/2532(2020)

${ }^{4}$ https://undocs.org/en/S/RES/2565(2021)
} 
(Forts.)

\begin{tabular}{|c|c|c|}
\hline Helsetema & Resolusjon (år) & Innhold (vinkling / tilretteleggende faktorer) \\
\hline & & $\begin{array}{l}\text { Vinkling 2565: } \\
\text { - Gjentar fokus på konflikt, etter konflikt eller i humanitær krise og } \\
\text { krav om våpenhvile } \\
\text { - Tydelig fokus på løsninger gjennom ACT-A og COVAX og å } \\
\text { sikre vaksinedistribusjon, samt rettferdig tilgang generelt, og det } \\
\text { internasjonale ansvar. Tydelig fokus på covid-19-teknologi og } \\
\text { tilgjengeliggjøring, gjennom ulike mekanismer (inkl. donasjon, } \\
\text { manufacturing) og humanitær setting spesielt. } \\
\text { - Påpeker hvordan covid-19-pandemien er en trussel for langsiktig } \\
\text { fred og sikkerhet. }\end{array}$ \\
\hline \multirow[t]{2}{*}{$\begin{array}{l}\text { Beskyttelse av } \\
\text { medisinsk og } \\
\text { humanitært } \\
\text { personell i } \\
\text { konflikt }\end{array}$} & $2286(2016)^{5}$ & $\begin{array}{l}\text { Vinkling: } \\
\text { - Fordømmelse av vold mot helsesystem. } \\
\text { - Oppfordring UNSG til å gripe inn forebyggende og for bedre data } \\
\text { og rapportering. }\end{array}$ \\
\hline & & $\begin{array}{l}\text { Tilretteleggende faktorer: } \\
\text { - Grunnarbeid og behandling i WHO i for- og etterkant av resolusjon, } \\
\text { inkl. oppfølging. } \\
\text { - Ligger tett opp mot SR fokus på konfliktområder. }\end{array}$ \\
\hline \multirow[t]{3}{*}{ Ebola } & $\begin{array}{l}2177(2014), \\
\text { DRC (2018) }\end{array}$ & $\begin{array}{l}\text { Vinkling: } \\
\text { - Utbrudd som trussel for internasjonal fred og sikkerhet, med } \\
\text { mulighet til å reservere framgang og fare for uro, ustabilitet og } \\
\text { forverring av politisk og sikkerhetspolitisk klima. Innvirkning på } \\
\text { matsikkerhet, handel og reise. } \\
\text { - Understreket viktighet av FNs rolle i en helsekrise og bidro til å } \\
\text { mobilisere ressurser. }\end{array}$ \\
\hline & & $\begin{array}{l}\text { Tilretteleggende faktorer: } \\
\text { - Drevet fram av «failure av WHO» i å håndtere ebolautbrudd i } \\
\text { Guinea, Liberia og Sierra Leone. } \\
\text { - Oppmerksomhet fra sivilt samfunn om økt humanitær innsats } \\
\text { - UNSG: Anerkjente viktighet, tydeliggjorde mulige politiske, sosiale, } \\
\text { humanitære og sikkerhetsaspekter av ebolautbruddet } \\
\text { - WHO DG: Ebola som en av de største utfordringene FN har stått } \\
\text { ovenfor i fredstid: en trussel for nasjonal sikkerhet ut over områdene } \\
\text { rammet av utbruddet. } \\
\text { - } 2177 \text { resolusjonen hadde } 130 \text { co-sponsorer (høyeste antall i SRs } \\
\text { historie). }\end{array}$ \\
\hline & & $\begin{array}{l}\text { Motstand: } \\
\text { - Uenighet om universell relevans, noen påpekte at det vesentlige var } \\
\text { helse- og utviklingsmessige utfordringer heller enn fred og sikkerhet. }\end{array}$ \\
\hline
\end{tabular}

\footnotetext{
${ }^{5}$ https://digitallibrary.un.org/record/827916
} 
Global helse og internasjonal fred og sikkerhet - implikasjoner for FNs sikkerhetsråd?

\begin{tabular}{|c|c|c|}
\hline Helsetema & Resolusjon (år) & Innhold (vinkling / tilretteleggende faktorer) \\
\hline HIV/AIDS & $\begin{array}{l}\text { Res. } 1308 \\
(2000){ }^{6} \\
\text { videre i } 2001 \text {, } \\
2003,2005 . \\
\text { Res. 1983 } \\
(2011)^{7}\end{array}$ & $\begin{array}{l}\text { Vinkling: } \\
\text { - Påvirkning av hiv/aids på militære og fredsbevarende styrker, inkl. } \\
\text { personell. } \\
\text { Motstand: } \\
\text { - UNSG: Så ikke hiv/aids som tradisjonell SR-sak } \\
\text { - Ikke alle land så hiv som en universell utfordring (Afrika hardest } \\
\text { rammet). }{ }^{8}\end{array}$ \\
\hline
\end{tabular}

Gjennom Dialogforumet for Norges rolle i Sikkerhetsrådet ønsket vi å bidra til å løfte denne tematikken og til å benytte forskernes ekspertise til å spille aktuell kunnskap inn i sikkerhetsrådsprosesser. I dette fokusnummeret har vi samlet mange av de viktigste innsiktene.

God lesning!

Hilsen,

Niels Nagelhus Schia (redaktør), Louise Olsson (gjesteredaktør) og Ida Rødningen (gjesteredaktør)

\footnotetext{
${ }^{6}$ https://digitallibrary.un.org/record/418823, se også McInnes \& Rushton, 'HIV/AIDS and security: where are we now?' (2010) 86 International Affairs 225, 228.

${ }^{7}$ https://www.unaids.org/sites/default/files/sub_landing/files/20110607_UNSC-Resolution1983_0.pdf

${ }^{8}$ Takk til Erik Kursetgjerde (NUPI) for research til tabellen.
} 